\title{
Is Governmentality the Missing Link for Greening the Economic Growth?
}

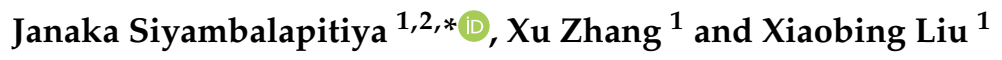 \\ 1 Department of Enterprise Management, Faculty of Management and Economics, \\ Dalian University of Technology, No. 02, Linggong Road, Dalian 116024, China; \\ xzhang@dlut.edu.cn (X.Z.); xbliu@dlut.edu.cn (X.L.) \\ 2 Faculty of Management, Department of Management Sciences, Uva Wellassa University of Sri Lanka, \\ Passara Road, Badulla 90000, Sri Lanka \\ * Correspondence: janaka@mail.dlut.edu.cn; Tel.: +86-155-6692-7379
}

Received: 28 September 2018; Accepted: 7 November 2018; Published: 14 November 2018

check for updates

\begin{abstract}
The new concept of "green growth" appears to be an economic growth model, which balances environment sustainability and fostering of economic growth. Yet, much of the green growth research has failed to address the real extent of interconnections and complexity of the relationship between governance and economic, social, and environmental structures. Furthermore, current green growth research tends to focus on the country level, such as the Millennium Development Goals and sustainable development indices, which risks ignoring the additional impacts on micro industrial economies. The lack of connection between green growth and good governance - known as environmental governance-is a crucial gap in practical adoption. Therefore, this study uses Foucault's governmentality lens to view green growth as a technique of government, seeking an environmentally focused eco-governmentality. We examine the transformation, differential definitions, and critical dimensions of green growth in relation to particular case studies taken from China and South Korea and frame them for future sustainable studies. The findings of this study highlight the significant role of interdisciplinary research, as well both bottom-up and top-down initiatives, on enabling the transition to green growth. The proposed research framework and implementation strategy also identifies new avenues for future research and practices in the field of sustainable development, making it one of the study's key contributions to the literature.
\end{abstract}

Keywords: green growth; circular economy; governmentality; environmental management; sustainable management; economic growth model; environmental sustainability

\section{Introduction}

In the face of global challenges such as climate change, rising greenhouse gas emissions, and environmental pollution, countries have begun to search for a suitable development strategy. Furthermore, repeated failures in other international policies have made it necessary to seek a new growth and development paradigm. Therefore, international agreements and discussions have started to balance economic growth with the depletion of natural resources $[1,2](p .7)$ stating that the "failure of critical climate negotiations has indicated that theories of sustainable development have not yet been effectively implemented in practical policies". Against this backdrop, one of the significant and meaningful current debates in the sustainable development paradigm has materialized as "green growth". This new approach involves "fostering economic growth and development while ensuring that natural assets continue to provide the resources and environmental services on which our well-being relies" [3]. This new concept "looks for promoting economic growth and development 
while balancing concerns about environmental degradation with the need for long-term economic growth" [4] (p. 2).

There is an improved increment in the literature that recognizes the emergence of this concept in history, but the exposure to green growth has been limited to the theoretical perspective, generally as another terminology for sustainable development. Furthermore, in many circumstances, the evolutionary research has not been developed based on evidence and therefore green growth is considered another label for sustainable development. Hence, in this article, the literature is conceptually analyzed to find the principle components of green growth in order to gain new insights to propose a research framework for a low-carbon footprint-as a strategy concerning all the mechanisms of green growth-with the help of evidence from successive stories from China and South Korea. For this purpose, the literature is reviewed based on an archival method [5], which enables the structuring of the research and building of a reliable knowledge base to propose a research framework for green growth. Therefore, the aim of this paper is two-fold. First, this study provides a quick historical overview of green growth and its evolution in order to provide distinct interpretations as researchers argue about new discourses for green growth in the direction of a circular economy at the micro level and the associated bond with governmentality at the macro level. Hence, augmentation highlights the essential functions of interdisciplinary research and an approach, considered from bottom-up and top-down, that promotes the transition to green growth, taking examples from China and South Korea. Secondly, the paper proposes a new research coordination framework for green growth, which is urgently needed. The methodological approach chart is shown in Figure 1. We believe this green growth research framework (Figure 2) could support the increase in the application of green growth in any environment.

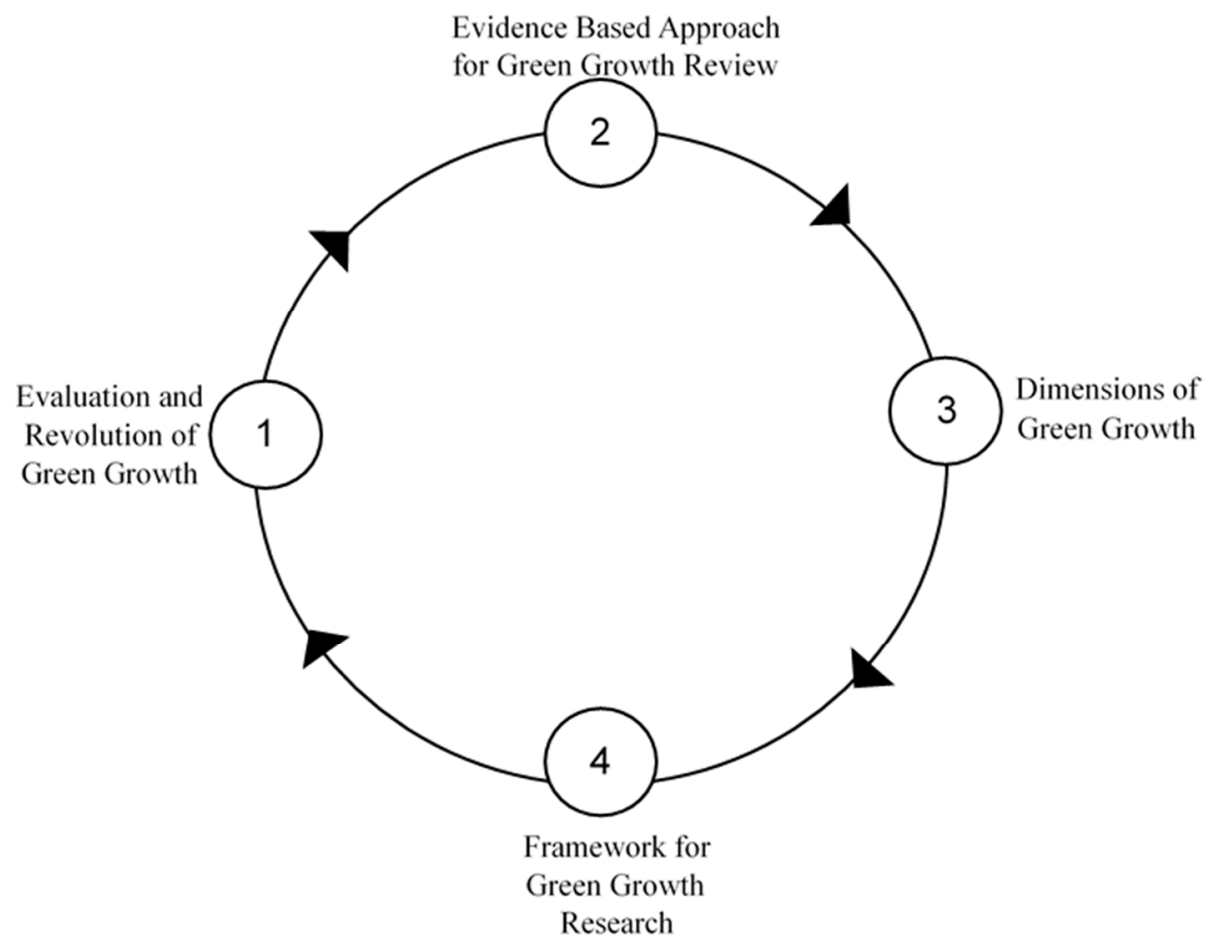

Figure 1. Methodological approach of the research.

\section{Background of Green Growth}

In the late 1940s and early 1950s, global events in the private and public arenas gradually started environmental movements, but it was a long process. In the recorded history during this decade, major conservation groups displayed an interest in pesticides or the environment. During the 1960s, public awareness of environmental problems rose, and the outgrowth of that was the formation of 
environmental sciences. This new science came alive to analyze complex environmental challenges and investigate ecological protocols. In her landmark environmental science book, Silent Spring, Carson [6] discussed how humans have acquired the power to alter nature, which has led to the universal contamination of the environment. During this period in the Western world, awareness of human environmental destructions increased due to notable environmental incidents. As the public became more conscious of environmental issues, their voices rose in the Earth Day demonstrations of 1970. In 1972, representatives of the Club of Rome built a world model and discussed it in detail in the book The Limits to Growth, which particularly examined five major trends of global concern [7]. Against this backdrop, the United Nations Conference on the Human Environment, having met at Stockholm in June 1972, considered the need for a shared vision and universal principles to stimulate and guide the world toward the protection and enhancement of the human environment.

One of the most prominent incidents took place in 1972 at a UN Conference on the Human Environment in Stockholm. It was here that the concept of "sustainable development" emerged. After the Stockholm meeting, global awareness of environmental issues drastically increased. In 1980, the World Conservation Strategy was prepared by the International Union for the Conservation of Nature and Natural Resources (IUCN), with the aim of advancing achievement of sustainable development through the conservation of living resources. In 1987, in his book Our Common Future, Brundtland stated that economic development issues and environmental problems are inseparable. These circumstances motivated the establishment of the World Commission on Environment and Development (WCED) by the UN General Assembly in 1983. It was a turning point and a new era for an economic growth protocol, which rationally argued about sustainable development policies for expanding the natural resource base. At the end of the 1980s, the concept of the green economy was first coined by environmental economists Pearce, Markandya, and Barbier of the UK in their book, Blueprint for a Green Economy [8].

After that, the Kyoto Protocol took place in 1992. However, the Kyoto procedures failed to deal with economic advancements and environmental issues [9]. This led to a major United Nations conference, the United Nations Conference on Environment and Development (UNCED), also known as the Rio Summit and Earth Summit, which took place in Rio de Janeiro in June 1992 with the participation of 172 governments, to come to an agreement about climate change convention. The later 2002 summit in Johannesburg made an effort to renew sustainable development through partnerships with the private sector [10] (p. 165). However, the summit discussed the possibility that governments could guarantee reaching the Millennium Development Goals (MDG) and enhance opportunities to create time frames and strategies to meet the agreements over the next five, ten, and fifteen years. Last but not least, in the recent past, countries have adopted the 2030 Agenda for Sustainable Development, and in 2016, the Paris Agreement on climate change entered into force with 175 nations with the aim of stopping rising global temperatures [11].

\section{The Origin and Evolution of Green Growth}

A transformation of the development paradigm took place during the Ministerial Conference on Environment and Development in Asia and the Pacific (UNESCAP) in 2005 to shift the "grow now and clean up later" attitude to that of making economic growth greener. UNESCAP believed that improving environmental sustainability, while reducing poverty, is essential for endeavors to reach sustainable development and a high quality of life in the region. Therefore, a new paradigm of green growth was promoted as the foundation for improving environmental sustainability and touching the millennium development goals in the area [12]. The first ministerial-level meeting on green growth was held in June 2009, and announcements were made to carry out green growth strategies in the Organization for Economic Cooperation and Development (OECD) member states as an answer to the current dilemma relating to emergency consumption and beyond and as an acknowledgment that "green and growth can go hand-in-hand" [13] (p. 1). 
In May 2010, UNESCAP countries started to follow the Incheon Declaration on green growth to address the current crisis by showing their intention to engage in green growth strategies [14]. Backing this foundation, the Republic of Korea launched the Global Green Growth Institute (GGGI) in 2010 and later converted it to an international treaty-based organization in 2012 at the Rio+20 Summit $[15,16]$. The OECD published its first Interim Report of the Green Growth Strategy at the Meeting of the OECD Council at Ministerial Level held in 2010, providing a better understanding of the green growth concept, difficulties faced in its execution, the benefits of green growth, and some of the actions being taken in the current crisis. Since then, OECD has done tremendous work toward developing a green growth strategy that provides agendas for nations, with the aim of guiding them toward reaching economic growth and development while battling with environmental problems and reducing environmental degradation and wasteful use of natural resources. The concept was further strengthened after the introduction of natural capital as an additional factor in the production of economic accounts by the OECD and the World Bank in 2011 and 2012, respectively [10].

\section{Definitions and Dialogues}

Green growth is a globally important approach to green economic growth, and the UNESCAP first initiated it in 2005 for emerging economies in Asia to introduce a new strategic model in low-carbon sustainable development [17]. UNESCAP first described green growth as a way "to harmonize economic growth with environmental sustainability while promoting the eco-efficiency of economic growth and enhancing the synergies between the environment and the economy" [11]. Later in 2015, UNESCAP identified the importance of natural capital for expanding the scope of the concept, thus making green growth a driver of economic growth that is environmentally sustainable. The OECD initially identified the concept in 2009 and redefined the idea as "fostering economic growth and development while ensuring that natural assets continue to provide the resources and environmental services on which our well-being relies" [3].

The World Bank identifies green growth as a model that could support the efficient use of natural resources while minimizing pollution and environmental impacts and ensuring resilience in natural hazards [18]. Furthermore, the World Bank extended the scope of green growth in the Inclusive Green Growth report in 2012, adding the role of environmental management and natural capital to avoid physical disasters [18].

The Global Green Growth Institute, as cited in Reference [19], identifies green growth as a "new revolutionary development paradigm that sustains economic growth while at the same time ensuring climate and environmental sustainability". Therefore, GGGI considers green growth in relation to the causes and the challenges of sustainable development while guaranteeing the formulation of essential channels for resource allocation and access to essential commodities for the impoverished [19]. Furthermore, GGGI—which is currently working on promoting green economic growth and development, environmental sustainability, poverty mitigation, and social inclusion-was prompted by the need to include sustainable development and consumption of global resources as new workings of green growth.

The definition of green growth provided by the Green Growth Knowledge Platform (GGKP) is identical to that of the OECD while focusing on the relationship between the environmental and economic pillars of sustainable development [20]. GGKP further states that green growth rejects the traditional convention of "grow first, clean up later" and lowers the interests of investment decisions that entrench socially and environmentally destructive carbon-intensive systems [20].

Green growth experts or historians have adequately covered the emergence of this concept and its evolution in history. However, this recently embraced terminology, which has been debated in connection with the economic transition for a sustainable economy, lacks a common definition. It is important to highlight that most organizations have consistently defined the same terminology, but the international bibliography on economic development, environmental degradation, and environmental 
governance is not mentioned, which is one of the most important functional components of green growth.

\section{Green Growth with Environment, Society, and the Economy}

In spite of the agreed definitions and frameworks, there is no clear evidence that many countries have applied and started to practice green growth in their national policies and strategies [21]. Schmalensee and Hallegate, in 2012 and 2011, respectively, stated that one of the major components of sustainable development, recognized as a "social pillar", is absent from green growth explanations [22]. Thus, it would be considered as a subset of sustainable development, where green growth explicitly addresses the needs of future generations. Nevertheless, OECD has proposed and stated that sustainability should be the central concept of the green growth strategy and has further identified that green growth is not a replacement for sustainable development. Indeed, green growth focuses on greening the growth of economies while achieving measurable progress in environmental and economic pillars [23]. However, the fundamental key concept of sustainable development and green growth remains the same and yet, the overall concept of sustainable development goes beyond green growth. This relationship, which was further identified by the Federal Statistical Office of Germany [2], is cited by van der Ploeg and Withagen [24] in their model of the relationship between green growth and sustainable development. Nevertheless, green growth is considered a globally relevant approach to sustainable economic growth and discovering new opportunities and potential for low-carbon sustainable development for fast-developing economies.

Reference [25] provides some examples of voluntary actions for reducing greenhouse gases and states that the benefits of these in many industries are not adequate in the global arena, as indicated by many green growth experts. Nevertheless, these activities in the supply chains of large corporations at the industry level could be transformed into green growth strategies, as evidenced by China in the implementation of circular economy concepts [26]. Reference [27] states that a standard foundation requires dealing with the industry and those who would advocate a significant transformation to reduce environmental emissions. Furthermore, many sustainability economists have suggested that natural resources should be consumed with minimum impact on the environment. Hence, Lorek and Spangenberg [28] stated that resources should be consumed in the production processes in the form of sustainable consumption. Moreover, they highlighted the missing links of the process-“political leadership", "the participation of the societies", and "organizations for sustainable economic development" [28] (p. 42).

Nevertheless, the literature on green growth and climate change is lacking. Hence, there is a deficit in providing sufficient theoretical support to overcome the current crisis and transition to green growth [29]. This may be the reason many nations pay just lip service to green growth, and the reason most countries, deep in their hearts, are still unsure about adopting green growth. Therefore, a need has arisen to trace and find out to what extent the new slogan of green growth has been achieved in the implementation of green development and what those principal components have contributed. Reference [30] argues that clear policies and action plans, government commitments, extensive structural changes, and strong legal and regularity framework support are needed to successfully implement green growth policies.

\section{Circular Economy}

Many of the past concepts, growth models, and discussions have tried to transform economies into green ones. The formation and elaboration of these ideas is thoroughly linked to the promotion of concepts such as the Millennium Development Goals, sustainable development, and green growth indicators. The current linear economy leads to the waste of precious resources and the overproduction of waste and does not account for adverse consequences in the environment. Hence, it has become clear that our current linear economic model of "take-make-dispose" cannot be sustained. Regarding volume, at the start of the economic system in 2010, some 65 billion tons of raw materials was 
consumed, and this number is supposed to grow to around 82 billion tons by 2020 [31]. Furthermore, most past economic paradigms catered for the national level and limited their focus to industrial-level consumption and production patterns. Therefore, this has led to a deficit in the relationship between national policies with industrial practices. Thus, a single-perspective model, i.e., either on national economic considerations or industrial-level considerations, has limited the transition to green growth, as evidenced in the literature.

The literature on circular economy (CE) is still in its infancy [32], although the concept is identified as "an industrial system that is restorative or regenerative by intention and design" [31] (p. 13). It substitutes the end-of-life concept with restoration and transformation to renewable energy, and the avoidance of the use of toxic chemicals, which worsen reuse and return to the environment, thereby aiming to eliminate waste through the redesign of business processes and business models [31]. Experts have emphasized that the transition to a new circular economic model is "estimated to be worth more than one trillion dollars in material savings" [31] (p. 13). Reports published by Ellen MacArthur Foundation McKinsey and Company [31] outlined some of the benefits of engaging in the circular economy, for example, the cost of reproduction of one mobile phone would be reduced by $50 \%$, washing machine customers could save roughly a third per wash cycle while the manufacturer would gain more profit if the washing machines were leased rather than sold, and finally, income could be generated from waste management in the household and in the hospitality sector.

Recently, the European Union (EU) has taken a particular interest in the circular economy package, and an impression of the circular economy was adopted by the European Commission in December 2015. This created significant impetus toward supporting the transition to a circular economy in the region [33], specifically focusing on reducing the energy consumption and carbon dioxide emissions levels [34]. Hence, the concept of circular economy is considered as a solution for harmonizing the goals of economic growth and environmental protection [35]. Thus, the circular economy has powerful synergies with the objectives of green growth.

\section{Circular Economy, Green Growth, and Governance Role}

The view of the circular economy has gained more momentum in the recent past as one of the prominent solutions for environmental sustainability [36]. CE has been conceptualized as "an industrial system, which is restorative or regenerative in terms of intention and design and aims to design out waste through the optimization of the cycles of products, components and materials by keeping them at their highest utility and value, distinguishing between technical and biological cycles" [37] (p. 15). Therefore, the circular economy process includes product life extension (reuse, refurbishment, and remanufacturing) and the reuse of old products as secondary resources (recycling) [38].

China was among the first nations to identify the inconsistency between economic development and the resultant environmental impacts. As a result, at the 11th National People's Congress of the People's Republic of China, the Government of China passed the Circular Economy Promotion Law, which was implemented in January 2009 [26]. Since the passing of this bill, several activities have ensued, including decrement (i.e., decline of resource consumption and waste creation in production, circulation, and consumption), recycling and resource recovery in production (i.e., straight use of wastes as raw materials, or waste regeneration), and circulation and consumption implemented by China. In addition, China's Five-Year Green Plans give substantial weight to green development, with 10 out of 25 preference targets related to the environment to be achieved by 2020. Furthermore, the Government of China plans to prevent and control environmental risks and improve environmental public services by lessening "carbon emissions per unit of GDP by $17 \%$ and energy usage and consumption per unit of GDP by $16 \%$ and raise the forest coverage by $21.66 \%$ " with the investment of around RMB 3.4 trillion [39]. One of the prominent factors of China's policy is taking precautions to reduce carbon emissions and consumption of energy, while expanding employment opportunities in industries such as energy, transportation, and forestry [40]. This can help the country reduce the environmental impact while achieving the defined environmental targets. 
South Korea, which has been a pioneer and leader in green growth, has lifted the achievement of a green economy to the national level and implemented an inclusive institutional system for the execution of green growth theory in practice [40]. In 2008, South Korea declared that it would reduce its greenhouse gas emissions by $30 \%$ from the usual business scenarios by 2020 and set mid-term to long-term low carbon green growth development plans (i.e., from 2009 to 2050). To move forward as a green growth initiator, the Government of South Korea launched its National Green Growth Strategy in 2009. This was backed by the National Emission Trading Scheme (ETS), which was supported by the Government of South Korea. Against this backdrop, the Korean Government took necessary actions to guide the country toward a low-carbon and energy-efficient green development. Currently, the Government has provided USD 83.6 billion investment, which is nearly $2 \%$ of the domestic GDP as public support [41]. The benefits were recorded to be slow, though with growing trends in the future (see Reference [42]). The success story behind the achievements in Korean strategy is the Government and private sector progressively recognizing the importance of applying low-carbon, energy-efficient development practices for achieving green sustainable development objectives.

\section{Green Growth and Good Governance}

The current green economic research has mainly focused either on the national level, such as Millennium Development Goals, sustainable development goals, green growth indicators, or at the industry level, such as recycling or the circular economy. In the process of implementation, the additional impact that may occur with interdisciplinary endeavors has been ignored. Therefore, in this study, a systematic approach to the literature review has been taken to find and build an interdisciplinary relationship for forming and framing a fundamental model for green growth. This study contributes to the interdisciplinary research by forming both bottom-up and top-down initiatives in proposing a green growth research model that binds all the essential components of green economy. Therefore, this study has provided new insights into green growth by facilitating both the bottom-up approach, by circular economy principles that have also been gradually integrated with green growth, and the top-down approach, by influencing green growth with the lenses of good governance.

Former UN Secretary-General, Kofi Annan, noted that "good governance is perhaps the single most important factor in eradicating poverty and promoting development" [43]. In the academic research, there is no ultimate definition of good governance, and different organizations understand the concept differently. However, we will consider modern theories that explain the concept for our own research purposes. According to Reference [44], governance indicates the structure and equipment prepared for controlling social change in predetermined directions. In this general context, the World Bank and other global development banks have explored good governance, which "addresses economic institutions and public-sector management, including transparency and accountability, regulatory reform, and public-sector skills and leadership" [45] (p. 7). Other organizations, such as the United Nations, European Commission, and OECD, are more likely to emphasize democratic governance and human rights aspects of political governance, which are avoided by the banks [45].

The two concepts of good governance and green growth go hand in hand and are closely tied, although good governance does not secure the execution of green growth strategy. However, its deficiency severely limits environmental sustainability. Even though better governance promotes economic development, "efficient and effective public management, transparency, and accountability, developmental objectives and influential political policies" (as cited by Gisselquist [45]) (p. 8) are the key areas that can cause a considerable impact in good governance. Many countries from Asia and the West have, more or less, illustrated some of these issues, although this will not be discussed in detail in this paper as it is not within the scope of this study.

On the other hand, some argue that good governance does not necessarily fit with green growth in a meaningful manner. As cited in Reference [45], some have argued that good governance has endless definitions and lacks differentiation, and as it does not have standard acceptance, researchers have 
defined the concept in whatever way best describes their data. However, there is an international unity and agreement on the need for strong governance as a basis for green growth and its interpretations. Even with the assurances shown by international and national organizations on different occasions, the regulatory control of state institutions are not prepared to move forward with green transformation. Furthermore, Kardos [46] notes that the limitations on governance are given in the complex context of today's sustainable development.

Determining the facts is necessary as some can argue as to whether political leadership and good governance are indeed the most important and fundamental factors for green sustainable development. They are also required for analyzing whether political leadership and good governance are adequate for environmental sustainability. Reference [47] stated that economic development is considered to be more important than environmental sustainability goals, especially in economies facing difficult periods, as evidenced by Canada and South Africa. Governance legislation matters for green development and, more importantly, "transparency, accountability and participation are inseparable elements of good governance and management" [47] (p. 556). Therefore, the concept of good governance and the allocation of scarce resources and regulators in the economic processes are far from involving government and civil society for green development, and the industry level calibration needs to play a significant role in this process in order to limit the drawbacks observed in the relevant research.

To address complicated global issues of green development, it is necessary and important to have a strategic approach that can provide the most suitable "framework for an integrated vision of all components taking part in the whole process" [46] (p. 1168). A process of decision-making and the process by which decisions are implemented may be linked and coordinated with the implementation of any strategy. If they are not organized or interrelated with common goals, the result will be failure. Therefore, we believe that the proposed research framework can be interrelated with all the significant components of green growth to address more complex issues.

\section{Governmentality for Green Growth}

The governor is used to describe the link between governing and the methods of thought as the mentality "indicates that it is not reasonable to study the technologies of power without an analysis of the political rationality underpinning them" [48] (p. 191). However, Lemke [48] considered another point of view — the concept of governmentality [49] — as equal in importance. Lemke [48] noted that Foucault has used the term governmentality in a broader sense, compared to traditional considerations of the term, and discussed the term with a "close link between forms of power and processes of subjectification" (p. 2). In Foucault's analysis of the phrase, the government is not only discussed in political territories, but also in philosophical, religious, medical, geographical, and educational texts [50] (p. 33). Furthermore, Foucault indicated that in "addition to the management by the state or the administration, the government also signified problems of self-control, guidance for the family and children, management of the household, directing the soul" [50] (p. 33). Hence, Foucault defined government as "conduct, or, more accurately, as the conduct of conduct"; therefore, the term ranges from "governing the self to governing others" [51] (p. 191). Seeing governance in this perspective [52] entails "not just the actions of the state and its institutions but more broadly any systematic effort to influence or guide the conduct of human beings through acting upon their hopes, desires, circumstances, or environment" [52] (p. 1) and also considers a range of activities of governance. Today, even though many understand the meaning of government solely from the political perspective, Lemke [48] argues that Foucault had seen the "problem of government placed in a more general" manner up to the 18th century [48] (p. 3). Therefore, Foucault identified and positioned the concept of governmentality as a "guideline for a genealogy of the modern state" [48] (p. 191).

In the literature, it is evident that many researchers have adopted Foucault's approach to governmentality in research areas, such as economic development, environmental activities, cultural studies, and landscape studies. For the development of the proposed research frame, this study has considered adopting Foucault's governmentality as a technique of government and its effects in order 
to build a bridge between governance and green growth. It is seen today that governments do not always practice governmentality in the way it is meant to be studied. Thus, we believe that activities of the state, seen through the governmentality approach, will work as a coordinating strategy for green growth in the 21st century. Therefore, governments will interpret the nature of the society in the most meaningful manner. Foucault developed three analytical dimensions with three analytical aspects. Foremost, "it presents a nominalist account that stresses the central importance of knowledge and political discourses in the constitution of the state" [53] (p. 1).

Reference [54] revealed that favorable involvement of political commitment and leadership, as well as the coordination of policies, requires building and developing a green economy. The knowledge and political dialogue on policy regulations and the measure of environmental concerns should strategically constitute the state while greening the whole economy. It is evident that the Korean strategy demonstrated leadership and commitment of the government in achieving green growth objectives, especially in reducing levels of carbon emissions from industrial activities [9]. Studies have also demonstrated evidence of $\mathrm{CO}_{2}$ emission reduction with governmental policies, such as public transport and waste using green energy in Malaysia [55], and public investments for greening the economy, such as seen in South Korea [56]. Therefore, as evidenced by China and South Korea, implementing good industrial policies are required to shift the energy system and reduce emission levels, and this should be backed by governments that focus on the development of future market platforms for new energy and low carbon technologies [9].

It is commonly accepted today that without proper environmental regulations, countries may face difficulties in energy markets. On the other hand, rigid and tight environmental regulations and policies may place an extra burden on economies, leading to slow growth. Therefore, to find a balance between environmental regulations and economic growth, governments need to design a flexible and smart environmental package of rules, regulations, and policies that are dynamically relevant [57]. The Korean strategy facilitates cooperative development between the economy and environment whenever the government launches and enforces a national policy in relation to the green economy. Thus, the Korean strategy carries through in different areas, such as funds and finance, science and technology, environment, the national land, and building sectors [58].

On the other hand, the OECD argues that green growth requires a mixed approach, including through policy instruments, market-based approaches, and regulations and standards [16] (p. 9). The OECD indicates that policy instruments and regulations are among the most common research agenda in practice, while a market-based approach in green growth is underestimated in the literature. Therefore, industrial-level approaches such as circular economy would support improvements in green growth by sharing the common objectives with systematic transformation, and this systemic change must look beyond the energy sector [27]. Furthermore, according to Porters' hypotheses, well-designed, environmental regulation mechanisms at the industry level will dramatically reduce emission levels and increase competition between rivals. This indicates that strict environmental rules may not bring about negative consequences but rather enhance companies' competitive advantage against rivals [59-61]. Reference [62] discussed some cases concerning Trojan horse greener economies, such as shifting harmful environmental activities to the other nations, which has no or fewer rules and regulations compared to alternative operations. This scenario is commonly evidenced in South Asian and African subcontinents, where polluted and toxic manufacturing is pulled out from the West and kept in operation in these subcontinents as these countries have less environmental regulations. This shows the importance of governing policies and the need for green regulations at national and international cross borders.

The second of Foucault's analytical dimensions in the history of governmentality is the "analytics of government using a broad concept of technology that encompasses not only material but also symbolic devices, including political technologies as well as technologies of the self" [53] (p. 1). Technologies of government are "the set of mechanisms, techniques and procedures through which programs are activated and put into practice" [63] (p. 296). Technoscientific knowledge from the 
governmentality perspective is about the environment, addressing changes, moving and fixing political agendas, achieving scientific advancements and improvements, and keeping the aims in connection with occupational trends [64]. Economies have to face difficulties in reaching sustainable development goals of greening the economy without improving the transparent and accountable decision-making systems of governance. Therefore, Reference [65] stated that transparency in environmental activities leads to improvement in accountability by increasing political pressure to support environmental performance. The whole process should follow up with adaptable and flexible command and control regulations by the government for green technology innovation [62]. In South Korea, it has been demonstrated that public investment in infrastructure and technology, such as improving water quality and seed funding pilot projects, has led to a transition to green systems [9]. Therefore, a mechanism is needed that relates to techniques and procedures of governing technology programs to be activated and put into practice.

The third of Foucault's analytical dimensions in the history of governmentality "considers the state as an instrument and political strategies that define the external borders between public, private, state and civil society, and also determines the internal structure of political institutions and state apparatuses" [53] (p. 1). Another factor in the successful development of green growth governmentality model is the different association with governmental coherences and connections, which Evans [66] (p. 12) considered an "embedded autonomy, providing the underlying structural basis for active state involvement in industrial transformation". In the real governance scenario, considering the participatory involvement of the population and inclusion and involvement of nonstate performers through partnerships [67] and the "conduct of conduct" as considered in Reference [68] (p. 4), the entire population can march in the direction of environmentally focused governmentality. This is evidenced in East Asia, which has provided some solutions for the coordination failures as governments get involved in and intervene beyond market-based competition and give priority to performance-based standards of success [62].

Reference [69] stated that Foucault's work is highly relevant and important for environmental thinking, hence mapping Foucault's ontology aids in the understanding and growth of various possible Foucauldian contributions made to critical environmental theory. Foucault's governmentality concept should be examined from a more thoroughly ecological standpoint, concerning broader and less ethnocentric and anthropocentric ontology. Therefore, it helps to rethink the concept core of political ecology as a historical ontology [70]. Hence, Foucault's governmentality concept goes beyond usual politics, which is under pressure in the current scenario due to various ecological rationalities of government [70]. Several scholars are now examining Foucault's genealogical concept to include ecological rationalities and technologies of the government, i.e., green or eco-governmentality [71]. The terminology of eco-governmentality or green governmentality has been identified in the recent past in the form of how power works through the construction of the environment and methods of providing solutions for environmental issues. Therefore, the solution provided in this study resolves the lack of connection between governance of the economy, environment, and community, leading to the possibility of rethinking the concept of green growth at the core of eco-governmentality from the viewpoint of political ecology. A study based on 15 cases and on an extensive literature survey [72] confirmed positive correlations between environmental governance and financial performance, meaning good governance can benefit the economy, whereas poor implementation of environmental governance may damage financial performance. Hence, it is evident that a strong link exists between environmental governance and the economy, environment, and society as a whole.

\section{Research Coordination Framework for Green Growth}

Reference [73] states that in the current global scenario, fewer gains in many productivity areas have been reported as environmental pressures keep rising. Hence, carbon emissions are reaching high levels, the consumption of fossil oil dominates the production processes, and many precious and useful resources continue to be disposed of as waste. Therefore, green growth must be rooted 
in the economic approach, as shown by many researchers, but a human touch in the environmental relationship is also necessary. Economic and social improvements go hand in hand in reducing inequity, as suggested by Hallegatte and cited by Reference [22]. Hence, the interconnected relationship with society outreaches social development. From this viewpoint, documentation and lip service is not enough in the green growth vision; rather, changing and transforming production and consumption patterns are vital on the road toward green development. Thus, someone following Foucault's viewpoint relating to the environment "must not identify it as a naturally given sphere or as a mysterious domain of obscure terrestrial events, which human knowledge works to explain" [64] (p. 6). It is evidenced that the Korean policy is focused on the promotion of technological development of primary industries as the next step as well as on export policies for reducing carbon emissions in the coming years [9]. Thus, the success is based on government policy coordination in South Korea, comprising national policy on the green economy, which enables the concurrent development of the economy and environment. Hence, an equal stabilized consideration leads to various areas, such as technology, funds and financing, building and land, and national cultures, from a comprehensive perspective [74]. Thus, considering the extensive literature, proposing an evidence-based research coordination framework for green growth (Figure 2) will provide new insights into the development of a paradigm that connects interrelating and interconnected activities relating to the environment, society, and economy through the comprehensive analysis of good governance. Thus, this study evolutionarily develops new ways of understanding the green growth concept and convergence on a single theoretical research framework. The emergent research framework is likely to be testable with the proposed components, which can be readily measured as the process of developing the research framework of green growth is tied with some living evidences. The developed framework is shown in Figure 2.

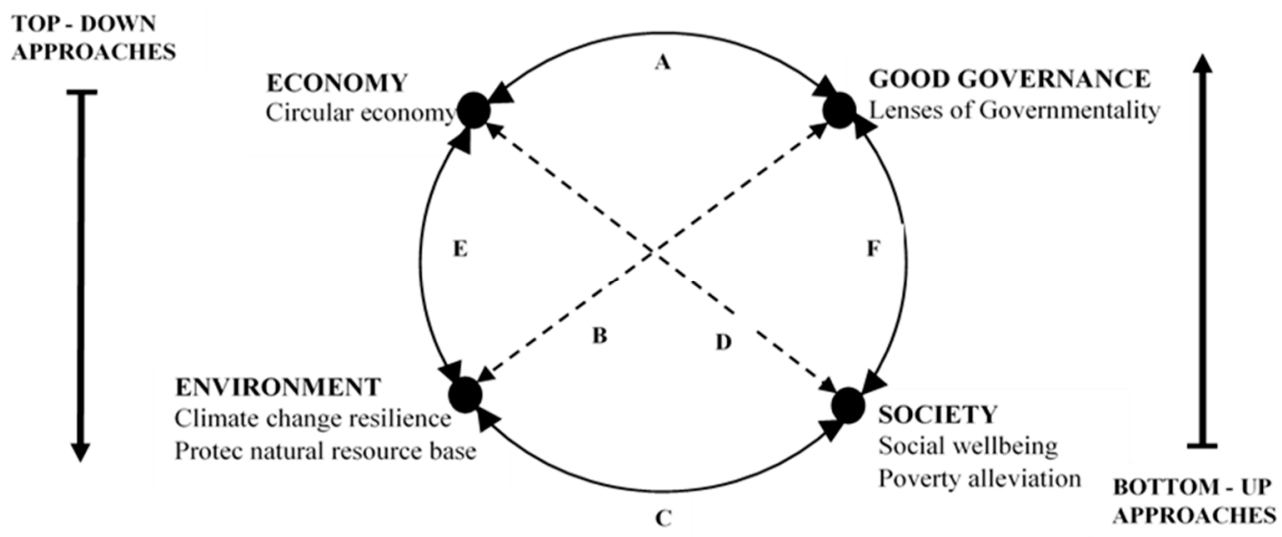

Figure 2. Frame of reference: four dimensions for green growth.

A: Technological transformation and public-private collaboration with policy regulations for green development through low-carbon circular economic strategies and its investments.

B: Protect and improve natural resource base through technoscientific approach for climate change resilience.

C: Improve social wellbeing and reform environmental climate change resilience.

D: Social contribution to the circular economy for green development and monetary and nonmonetary benefits for poverty alleviation.

E: Transform production and consumption patterns to reduce the impact and hazards in natural resource base in order to prevent environmental degradation.

F: State concern with governance of the wellbeing of society and society's responsibility of succeeding in gaining good governance.

Thus, in this review, green growth is demonstrated as a cycle of interrelated activities, which has a bottom-up and top-down approach, ensuring the use of natural resource base in a technoscientific 
manner by protecting the environment with minimum impact, by fostering economic growth and development, and influential support and cooperation from industries and governance supporting social development. Hence, it is important to highlight that this cycle's work mechanism is based on the ability to change and willingness to change from industry-level circular economic activities toward national-level green growth processes with the support of environmental governmentality. Therefore, the approach should be balanced and coordinated between governance, environment, society, and the economy. Imbalance or a lack of coordination could derail the greening of economic growth. A notable example in this scenario would be Indonesia, which has shown rapid economic development but also has many downsides because of the nonexistence of transparency and commonly reported corruption in economic management [75]. On the other hand, broad governmental support for green economic development in South Korea, China, and Taiwan bear witness to what coordination and interconnectedness can achieve.

\section{Evidence from East Asia}

Developing economies undergo fast development in areas such as agriculture, industry, trade, transport, and power resources; thus, a sustainable development paradigm is more vital for those regions. Developed countries mainly make significant investments in reducing $\mathrm{CO}_{2}$ emissions. Although it will increase living stands of people in the short term, this is not a sustainable approach to going green. It may make sense for wealthy countries-or in other words, developed countries-to cut $\mathrm{CO}_{2}$ emissions severely through conservation by converting to alternative energy resources. However, developing economies, especially Asia, have grabbed green opportunities by increasing investments in future green markets and growing the economy while reducing $\mathrm{CO}_{2}$ emissions. For example, South Korea, China, and Malaysia focus on future green markets in relation to the policy implications of green growth as an engine of growth.

Green growth initiatives in South Korea and China present valuable lessons for the rest of the developing nations. Concerning the two cases studied in this paper, China's green growth strategy is a bit narrower than South Korea's comprehensive plans, although China's current plans and actions are dedicated to green growth principals. As a result, green growth is subsidized among other alternatives and has become a solution for ongoing environmental pollution in the region. Furthermore, these lessons have shown the globe that environmental regulations may not slow economic growth and competitiveness unless there are many differences in policies among the counties [76]. On the other hand, job creation is an essential benefit of green growth policies, for example, China and South Korea stand among the world's largest green job creators, and China alone will have created 4.5 million green jobs by 2020. Therefore, multinational firms, such as Hyundai and Samsung, have entered new business models, especially in solar and wind power, electric vehicles, and zero-emission factories, responding to their own green growth strategies to cater for future markets. In these circumstances, the growth paradigm, which proposes to coordinate all the main constituents, is a requirement for developed as well as for developing nations.

\section{Contributions and Conclusions}

Although most of the academic and practitioner work on green growth has examined the concept, the definition of green growth is not yet entirely clear. It is still debatable in the literature from the broader perspective, such as poverty alleviation, environmental protection or greening the economies. Furthermore, recent studies on green growth have been incapable of providing sufficient evidence to support solving the current crisis. Reference [30] argued the need to implement green growth policies successfully, such as action plans, strong government commitment and support, structural changes when needed, and legal and regulatory frameworks. Against this backdrop, this study draws on the theory of Foucault's governmentality, considering it broadly in connection with the ecological standpoint rather than as another concept of historical ontology. This provides new insights into green growth for conceptualizing the relationship between the environment, society, and economy, 
with policy evidence cases taken from the Asia Pacific. Hence, the proposed model interrelates and interlinks the economy, governance, environment, and community to accomplish green growth in any environment.

While many criticisms have stressed that sustainable development is too abstract and straightforward [77], green growth has attracted the attention of many economies that are grappling with the economic transition to a sustainable economy. Therefore, this review has provided a brief historical overview of green growth and its evolution in order to indicate the distinct interpretations. We argue for a new discourse on green growth in relation to governmentality and economic and social structures. Therefore, this analytical study has presented a review of the historical background of the concept, from the early 1940s to its emergence in 2017, through the study of relevant documents. Having identified the transformation of green growth, this study has briefly examined all the key definitions and finally concluded with a new practical insight into the green growth paradigm. Therefore, the proposed research frame induces a paradigm shift in the way of understanding the connections between greening the economy and governance, environment, and community. Hence, green growth is identified by ensuring the use of natural resources in a technoscientific manner by protecting the environment with minimum impact. This is achieved by fostering economic growth and development with substantial support and cooperation between industries and governance to promote social development.

This study presents one of the first research frameworks that incorporates Foucault's governmentality in providing a new approach to the green growth concept. Furthermore, the proposed model interrelates and interlinks the economy, governance, environment, and community to accomplish green growth in any environment. Therefore, this new approach emphasizes the inclusion of green growth alongside the management of social dimensions into the main framework-factors that have been depreciated or even overlooked in the present context. This new framework will possibly act as a bridge between differential modes of thinking. Therefore, this study has presented evolutionarily developed new ways of understanding the green growth concept and has converged it on a single theoretical evidence-based research framework, which is one of this study's contributions to the literature.

Author Contributions: For this research article, all the authors contributed equally to the conceptualization, methodology, and design of the reference research model. Writing and paper preparation by J.S.; Review and editing by X.Z.; Supervision by X.L.

Funding: Funds were provided by the National Natural Science Foundation of China, International Comparison of Green Growth Theories and Practice-No. 71320107006.

Acknowledgments: We acknowledge the National Natural Science Foundation of China for supporting us in conducting this study under project No. 71320107006.

Conflicts of Interest: The authors declare no conflict of interest.

\section{References}

1. Kim, S.E.; Kim, H.; Chae, Y. A new approach to measuring green growth: Application to the OECD and Korea. Futures 2014, 63, 37-48. [CrossRef]

2. Federal Statistical Office of Germany. Test of the OECD Set of Green Growth Indicators in Germany; Statistisches Bundesamt (Federal Statistical Office): Wiesbaden, Germany, 2012.

3. Cabrita, M.; Cruz-Machado, V.; Matos, F.; Safari, H. Green Knowledge: Developing a Framework that Integrates Knowledge Management and Eco-Innovation. In Proceedings of the European Conference on Knowledge Management, Belfast, UK, 1-2 September 2016.

4. Popp, D. The Role of Technological Change in Green Growth; Centre for Policy Research, The Maxwell School, Syracuse University: New York, NY, USA, 2011.

5. Tranfield, D.; Denyer, D.; Smart, P. Towards a methodology for developing evidence-informed management knowledge by means of systematic review. Br. J. Manag. 2003, 14, 207-222. [CrossRef] 
6. Carson, R. Excerpts from Silent Spring. In The American Reader: Words that Moved a Nation; Harper Collins: New York, NY, USA, 1962; pp. 323-325.

7. Meadows, D.H.; Meadows, D.; Randers, J.; Behrens, W.W., III. The Limits to Growth: A Report to The Club of Rome; Universe Books: New York, NY, USA, 1972; pp. 1-9.

8. United Nations Economic and Social Council. Ministerial Declaration on Environment and Development in Asia and the Pacific. In Proceedings of the Ministerial Conference on Environment and Development in Asia and the Pacific, Seoul, Korea, 28-29 March 2005.

9. Mathews, J.A. Green growth strategies-Korean initiatives. Futures 2012, 44, 761-769. [CrossRef]

10. Bartelmus, P. The future we want: Green growth or sustainable development. Environ. Dev. 2013, 7, 165-170. [CrossRef]

11. United Nations (UN). Framework Act on Low Carbon, Green Growth Grounds for Enactment of Framework. 2017. Available online: http://unpan1.un.org/intradoc/groups/public/documents/apcity/unpanc (accessed on 29 August 2017).

12. United Nations Economic and Social Commission for Asia and the Pacific (UNESCAP). Ministerial Conference on Environment and Development, Fifth Session. 2005. Available online: https:/ /www.unescap. org/events/ministerial-conference-environment-and-development-asia-and-pacific-2005 (accessed on 14 April 2017).

13. Organisation for Economic Co-operation and Development (OECD). Declaration on Green Growth, Adopted at the Meeting of the Council at Ministerial Level on 25 June 2009. 2011, pp. 1-2. Available online: http: / / www.oecd.org/env /44077822.pdf (accessed on 19 April 2017).

14. United Nations Economic and Social commission for Asia and the pacific (UNESCAP). Green Growth, Resources and Resilience: Environmental Sustainability in Asia and the Pacific. UNESCAP, ADB, and UNEP. 2012. Available online: http:/ / www.unescap.org/green-growth-resources-and-resilience-environmentalsustainability-asia-and-pacific (accessed on 11 April 2017).

15. Global Green Growth Institute (GGGI). Green Growth Planning GGGI Country Programs. 2012. Available online: http:/ / www.gggi.org/project/main (accessed on 14 October 2017).

16. Organisation for Economic Cooperation and Development (OECD). OECD Factbook 2010-Economic, Environmental and Social Statistics; OECD Publishing: Paris, France, 2010.

17. United Nations. State of the Environment in Asia and the Pacific 2005-Synthesis: Economic Growth and Sustainability; Economic and Social Commission for Asia and the Pacific: Bangkok, Thailand, 2005; pp. 1-34.

18. The World Bank. Inclusive Green Growth: The Pathway to Sustainable Development; International Bank for Reconstruction and Development/International Development Association or the World Bank: 2012. Available online: http: / / www.worldbank.org (accessed on 10 February 2017).

19. UN Division for Sustainable Development (UNDSD). A Guidebook to the Green Economy. 2012, p. 51. Available online: http: / / sustainabledevelopment.un.org (accessed on 11 March 2016).

20. Green Growth Knowledge Platform (GGKP). 2017. Available online: http:/ / www.greengrowthknowledge. org/page/explore-green-growth (accessed on 19 July 2017).

21. Zelenovskaya, E. Green Growth Policy in Korea: A Case Study; International Centre for Climate Governance: San Giorgio Maggiore, Italy, 2012.

22. Organisation for Economic Co-operation and Development (OECD). Tools for Delivering on Green Growth. 2011, p. 129. Available online: http:/ / www.oecd.org/greengrowth/48012326.pdf\%5Cnpapers2: / / publication/uuid/01A47214-EE20-4382-BD3D-275469F9A477 (accessed on 3 March 2017).

23. Organisation for Economic Co-Operation and Development (OECD). Towards Green Growth. Growth: A Summery for Policy Makers; OCED Printing: Paris, France, 2011.

24. Van Der Ploeg, R.; Withagen, C. Green Growth, Green Paradox and the global economic crisis. Environ. Innov. Soc. Transit. 2013, 6, 116-119. [CrossRef]

25. Plambeck, E.L. Reducing greenhouse gas emissions through operations and supply chain management. Energy Econ. 2012, 34, S64-S74. [CrossRef]

26. The Standing Committee of the National People's Congress China. Circular Economy Promotion Law of the People's Republic of China. Order of the President of the People's Republic of China. 2008. Available online: http:/ / www.fdi.gov.cn/1800000121_39_597_0_7.html (accessed on 25 January 2018).

27. Zsyman, J.; Huberty, M. Green growth. Intereconomics 2012, 47, 140-164. [CrossRef] 
28. Lorek, S.; Spangenberg, J.H. Sustainable consumption within a sustainable economy-Beyond green growth and green economies. J. Clean. Prod. 2014, 63, 33-44. [CrossRef]

29. Zhang, Y. Climate Change and Green Growth: A Perspective of the Division of Labour. China World Econ. 2014, 22, 93-116. [CrossRef]

30. Ates, S.A. Economic Planning and Industrial Policy in the Globalizing Economy. Development Planning in Twenty-First Century. 2015, pp. 345-354. Available online: http:/ /link.springer.com/10.1007/978-3-31906474-1 (accessed on 14 December 2017).

31. Ellen MacArthur Foundation McKinsey and Company. Towards the Circular Economy: Accelerating the Scale-Up across Global Supply Chains; World Economic Forum: Geneva, Switzerland, 2014; pp. 1-64. [CrossRef]

32. Pomponi, F.; Moncaster, A. Circular economy for the built environment: A research framework. J. Clean. Prod. 2017, 143, 710-718. [CrossRef]

33. European Commission. COM (2017) 33 Final Report from the Commission to the European Parliament, the Council, the European Economic and Social Committee and the Committee of the Regions on the Implementation of the Circular Economy Action Plan. 2017, pp. 1-14. Available online: http:/ / ec.europa. eu/environment/circular-economy/implementation_report.pdf (accessed on 9 March 2018).

34. European Commission. Circular Economy 2017. Available online: http://ec.europa.eu/environment/ circular-economy (accessed on 9 March 2018).

35. Lieder, M.; Rashid, A. Towards circular economy implementation: A comprehensive review in context of manufacturing industry. J. Clean. Prod. 2016, 115, 36-51. [CrossRef]

36. Murray, A.; Skene, K.; Haynes, K. The circular economy: An interdisciplinary exploration of the concept and application in a global context. J. Bus. Ethics 2017, 140, 369-380. [CrossRef]

37. Ellen MacArthur Foundation. The New Plastics Economy: Rethinking the Future of Plastics. Ellen MacArthur Foundation, 2016. Available online: http:/ / www.ellenmacarthurfoundation.org/publications (accessed on 11 March 2018).

38. Stahel, W.R. Circular Economy. A new relationship with our goods and materials would save resources and energy and create local jobs. Nature 2016, 531, 435. [CrossRef] [PubMed]

39. Organisation for Economic Co-operation and Development (OECD). Green Growth in Action: China. Available online: http:/ / www.oecd.org/china/greengrowthinactionchina.htm (accessed on 19 March 2018). Green Growth in Action: Korea. Available online: http:/ / www.oecd.org/Korea (accessed on 19 March 2018).

40. Pan, J.; Ma, H.; Zhang, Y. Green Economy and Green Jobs in China; World Watch Report 185; World Watch Institute: Washington, DC, USA, 2011.

41. Kamal-Chaoui, L.; Grazi, F.; Joo, J.; Plouin, M. The Implementation of the Korean Green Growth Strategy in Urban Areas. In OECD Regional Development Working Papers 2011/02; OECD Publishing: Paris, France, 2011.

42. Cho, M. Is the Green Economy Secure in Korea? Dissecting Korea's Green Growth Strategy. In Interconnections of Global Problems in East Asia; Nautilus Institute, Hanshin University: Seoul, Korea, 2010; pp. 1-7.

43. United Nations University (UNU). 2012. Available online: http://unu.edu/publications/articles/whatdoes-good-governance-mean.html (accessed on 14 December 2017).

44. Lafferty, W.M. (Ed.) Governance for Sustainable Development: The Challenge of Adapting form to Function; Edward Elgar Publishing: Cheltenham, UK, 2004.

45. Gisselquist, R.M. Good Governance as a Concept, and Why This Matters for Development Policy; Working Paper No. 2012/30; UNU-WIDER: Helsinki, Finland, 2012.

46. Kardos, M. The reflection of good governance in sustainable development strategies. In Proceedings of the 8th International Strategic Management Conference, Barcelona, Spain, 21-23 June 2012; pp. 1166-1173.

47. Cash, C. Good governance and strong political will: Are they enough for transformation? Land Use Policy 2016, 50, 301-311. [CrossRef]

48. Lemke, T. The birth of bio-politics: Michel Foucault's lecture at the College de France on neo-liberal governmentality. Econ. Soc. 2001, 30, 190-207. [CrossRef]

49. Foucault, M. Governmentality. In The Foucault Effect: Studies in Governmentality; Burchell, G., Gordon, C., Miller, P., Eds.; University of Chicago Press: Chicago, IL, USA, 1991; pp. 87-104.

50. Lemke, T. Foucault's hypothesis from the critique of the juridico-discursive concept of power to an analytics of government. Parrhesia 2010, 9, 31-43.

51. Lemke, T. Foucault Governmentality and Critique. Rethink. Marx. 2002, 14, 49-64. [CrossRef] 
52. Inda, J.X. Anthropologies of Modernity: Foucault, Governmentality, and Life Politics. In Analytics of the Modern: An Introduction; Wiley-Blackwell: Hoboken, NJ, USA, 2008; pp. 1-20. ISBN 978-0-631-22826-4.

53. Lemke, T. An indigestible meal? Foucault, governmentality and state theory. Distinktion Scand. J. Soc. Theory 2007, 8, 43-64. [CrossRef]

54. Huhtanen, T. Europe and Green Growth: The Key to Recovery? Springer: Paris, France, 2010.

55. Begum, R.A.; Sohag, K.; Abdullah, S.M.S.; Jaafar, M. $\mathrm{CO}_{2}$ emissions, energy consumption, economic and population growth in Malaysia. Renew. Sustain. Energy Rev. 2015, 41, 594-601. [CrossRef]

56. Heidari, H.; Turan Katircioğlu, S.; Saeidpour, L. Economic growth, $\mathrm{CO}_{2}$ emissions, and energy consumption in the five ASEAN countries. Int. J. Electr. Power Energy Syst. 2015, 64, 785-791. [CrossRef]

57. Han, T.; Kim, G.; Lim, D. Green Growth: Managing the Transition to a Sustainable Economy. In Greening of Industry Networks Studies; Fossgard-Moser, T., Tsai, T., Lu, Y., Eds.; 2012; pp. 147-171. Available online: http:/ / dx.doi.org/10.1007/978-94-007-4417-2_8 (accessed on 20 May 2017).

58. Office for Government Policy Coordination-South Korea. Framework Act on Low Carbon, Green Growth. 2013. Available online: http: / / www.law.go.kr/lsInfoP.do?lsiSeq $=142380 \& c h r C l s C d=010203 \& u r l M o d e=$ engLsInfoR\&viewCls=engLsInfoR\#0000 (accessed on 20 May 2017).

59. Ambec, S.; Barla, P. A theoretical foundation of the Porter hypothesis. Econ. Lett. 2002, 75, 355-360. [CrossRef]

60. Ambec, S.; Cohen, M.A.; Elgie, S.; Lanoie, P. The Porter Hypothesis at 20: Can Environmental Regulation Enhance Innovation and Competitiveness. Rev. Environ. Econ. Policy 2013, 7, 2-22. [CrossRef]

61. Mohr, R.D. Technical Change, External Economies, and the Porter Hypothesis. J. Environ. Econ. Manag. 2002, 43, 158-168. [CrossRef]

62. Vazquez-Brust, D.; Smith, A.; Sarkis, J. Managing the transition to critical green growth: The "Green Growth State". Futures 2014, 64, 38-50. [CrossRef]

63. MacKinnon, D. Managerialism, governmentality and the state: A neo-Foucauldian approach to local economic governance. Political Geogr. 2000, 19, 293-314. [CrossRef]

64. Luke, T.W. Generating Green Governmentality: A Cultural Critique of Environmental Studies as a Power/Knowledge Formation. 1996. Available online: http:/ /www.cddc.vt.edu/tim/tims/Tim514a.htm128 (accessed on 3 January 2017).

65. Glemarec, Y.; Puppim de Oliveira, J.A. The Role of the Visible Hand of Public Institutions in Creating a Sustainable Future. Public Adm. Dev. 2012, 32, 200-214. [CrossRef]

66. Evans, P. Transformation. In Embedded Autonomy; University Press: Princeton, NJ, USA, 1995.

67. Scott, C. Governmentality and Strategic Environmental Assessment: Challenging the Sea/Good Governance Nexus. J. Environ. Assess. Policy Manag. 2011, 13, 67-100. [CrossRef]

68. Gordon, C. Governmental Rationality: An Introduction. In The Foucault Effect: Studies in Governmentality with Two Lectures by and an Interview with Michel Foucault; Burchell, G., Gordon, C., Miller, P., Eds.; University of Chicago Press: Chicago, IL, USA, 1991; pp. 1-51.

69. Darier, E. Foucault and the Environment: An Introduction. In Discourses of the Environment; Darier, E., Ed.; Blackwell Publishers: Malden, MA, USA, 1999; pp. 1-34.

70. Malette, S. Green Governmentality and Its Closeted Metaphysics: Toward an Ontological Relationality; University of Victoria: Victoria, BC, Canada, 2010.

71. Malette, S. Foucault for the Next Century: Eco-Governmentality. In A Foucault for the 21st Century: Governmentality, Biopolitics and Discipline in the New Millennium; Binkley, S., Capetillo, J., Eds.; Cambridge Scholars Publishing: Cambridge, UK, 2009.

72. White, A.; Kiernan, M. Corporate Environmental Governance: A Study into the Influence of Environmental Governance and Financial Performance; The Environmental Agency: Bristol, UK, 2004.

73. Organisation for Economic Co-operation and Development (OECD). Towards Green Growth: Monitoring Progress: OECD Indicators. Innovation. 2011, pp. 1-143. Available online: http:/ /www.oecd-ilibrary.org/ environment/towards-green-growth_9789264111318-en (accessed on 14 April 2017).

74. Statistics Korea. Korea's Green Growth: Based on OECD Green Growth Indicators. 2012. Available online: http:/ / www.oecd.org/greengrowth/Korea \T1 \textquoterightsGGreportwithOECDindicators.pdf (accessed on 1 April 2017).

75. de A. Samarasinghe, S.W.R. Democracy and Democratization in Developing Countries; Series on Democracy and Health; Department of Population and International Health, Harvard School of Public Health: Boston, MA, USA, 1994. 
76. Bowen, A.; Duffy, C.; Fankhauser, S. “Green Growth” and the New Industrial Revolution. 2016. Available online: http:/ / www.lse.ac.uk/grantham/ (accessed on 14 April 2017).

77. Bartelmus, P. Greening the National Accounts: Approach and Policy Use; United Nations Department of Economic and Social Affairs: New York, NY, USA, 1999.

(c)

(C) 2018 by the authors. Licensee MDPI, Basel, Switzerland. This article is an open access article distributed under the terms and conditions of the Creative Commons Attribution (CC BY) license (http://creativecommons.org/licenses/by/4.0/). 